\title{
An old taxonomic dilemma: the identity of the western south Atlantic lebranche mullet (Teleostei: Perciformes: Mugilidae)
}

\author{
NAÉRCIO A. MENEZES ${ }^{1}$, CLÁUDIO DE OLIVEIRA² \& MAURO NIRCHIO ${ }^{3}$ \\ 'Museu de Zoologia, Universidade de São Paulo, Caixa Postal 42494, 04218-970, São Paulo,SP, Brazil. E-mail: naercio@usp.br \\ ${ }_{2}^{2}$ Departamento de Morfologia, Instituto de Biociências, Universidade Estadual Paulista, 18618-000, Botucatu, SP, Brazil. \\ E-mail: cláudio@ibb.unesp.br \\ ${ }^{3}$ Escuela de Ciências Aplicadas del Mar, Universidad de Oriente, Apartado Postal 147, Porlamar, Isla de Margarita, Venzuela. \\ E-mail:nirchio@cantv.net
}

\begin{abstract}
The identification of the lebranche mullet in the western south Atlantic has long been problematical. In most recent works either Mugil liza Valenciennes and M. platanus Günther, 1880 or M. liza and M. cephalus Linnaeus, 1758 were recognized from the region and more rarely the occurrence of only one species has been proposed but without sufficient morphological, biochemical or molecular data to allow the designation of the taxonomically appropriate name. Analysis of meristic and morphometric data taken from samples collected from Venezuela to Argentina, clearly indicates that there is only one species of lebranche mullet in the Caribbean Sea region and the Atlantic coast of South America and that Mugil liza is the appropriate name. The comparison of the combined data from all the samples of M. liza with the data taken from one sample of $M$. cephalus that originated in the Mediterranean, the possible locality from which type specimens were collected (Eschmeyer and Fricke, 2009), revealed significant differences indicating that they are different species. It is also suggested that individuals from the western north Atlantic identified as M. cephalus might represent a population of $M$. liza in this region.
\end{abstract}

Key words: Mugilid species, Taxonomy, Misidentification, Caribbean and South American Atlantic waters

\section{Resumo}

A identificação da tainha que ocorre no Atlântico sul ocidental tem sido exaustivamente discutida e é problemática. Nos trabalhos mais recentes Mugil liza Valenciennes, 1836 e M. platanus Günther, 1880 ou M. liza e M. cephalus Linnaeus, 1758 foram reconhecidas e mais raramente a ocorrência de apenas uma espécie foi sugerida sem dados suficientes, tanto morfológicos como bioquímicos ou moleculares para possibilitar a designação do nome taxonomicamente mais apropriado. A análise de dados merísticos e morfométricos obtidos de amostras coletadas da Venezuela à Argentina, indica claramente a existência de uma só espécie de tainha na região do Caribe e na costa Atlântica da América do Sul e Mugil liza é o nome que deve ser a ela atribuído. A comparação dos dados de todas as amostras combinados com uma amostra de M. cephalus obtida do Mediterrâneo, considerado como a provável localidade de onde os exemplares-tipo foram coletados (Eschmeyer and Fricke, 2009), revelou diferenças significantes indicando que elas são espécies distintas. Também é sugerido que indivíduos do Atlântico norte ocidental identificados como M. cephalus podem representar apenas uma população de M. liza nesta região.

\section{Introduction}

The identification and distribution of the lebranche or striped mullet in the Atlantic waters of South America has long been controversial. Thomson (1963) considered Mugil cephalus Linnaeus, 1758 to be widely 